\begin{tabular}{|c|c|c|}
\hline & Int.J.Curr.Microbiol.App.Sci (2016) 5(7): 990-999 & \multirow{2}{*}{ 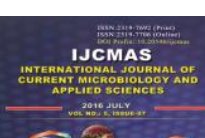 } \\
\hline & \multirow{4}{*}{$\begin{array}{l}\text { International Journal of Current Microbiology and Applied Sciences } \\
\text { ISSN: 2319-7706 Volume } 5 \text { Number } 7 \text { (2016) pp. 990-999 } \\
\text { Journal homepage: } \underline{\text { http://www.ijcmas.com }}\end{array}$} & \\
\hline & & \\
\hline EXCELLENT & & \\
\hline PUBLISHERS & & www.jijemas \\
\hline
\end{tabular}

Original Research Article

http://dx.doi.org/10.20546/ijcmas.2016.507.111

\title{
Incidence of Aeromonas species isolated from Diarrhoea patients and water samples from coastal districts of Odisha, India
}

\author{
Bibhuti Bhusan Pal ${ }^{1 *}$, Sanjay Kumar Pattnaik ${ }^{1}$, Anima Mohanty ${ }^{1}$, Surya Kanta Samal, \\ Hemant Kumar Khuntia ${ }^{1}$ and Sukanta Kumar Nayak ${ }^{2}$ \\ ${ }^{1}$ Regional Medical Research Centre (ICMR), Chandrasekharpur, Bhubaneswar-751023, India \\ ${ }^{2}$ Central Institute of Freshwater Aquaculture (CIFA), Kausalyanga, \\ Bhubaneswar - 751002, India \\ *Corresponding author email id:
}

A B S T R A C T

Keywords

Diarrhoea,

Aeromonas spp.,

Antibiotic

sensitivity,

Odisha

\section{Article Info}

Accepted:

28 June 2016

Available Online:

10 July 2016
A comprehensive study was performed to examine the incidence of different Aeromonas species, their drug sensitivity patterns and virulence genes isolated from diarrhoea patients and environmental water samples between September, 2006 to August, 2007 in Odisha. The rectal swab and water samples were bacteriologically analyzed using standard techniques; detection of toxic and clonality were done by PCR and RAPD-PCR Assay respectively. Out of 280 diarrhoea samples and 100 water samples, $20.2 \%$ from diarrhoea patients and $62.5 \%$ from water samples were positive for Aeromonas spp. A. hydrophila (50.9\%) was isolated as dominant pathogen followed by A. caviae $(27.2 \%)$ and $A$. sobria $(21.8 \%)$. The common resistance profile of three different Aeromonas species were piperacillin, kanamycin, bacitracin, rifampicin, erythromycin, sulfadiazine, roxithromycin, lomefloxacin, ciprofloxacin, ampicillin, furazolidone, cefuroxime, and amoxycillin. On blood agar plates 52.7\% of Aeromonas spp. showed $\beta$ - hemolysis and production of hly A gene as revealed by PCR assay. RAPD PCR assay revealed that the Aeromonas spp. were quite similar in clonality. As diarrhoea is the most promising health problem in Odisha, this type of study should be extended for longer period in different parts of the state.

\section{Introduction}

Aeromonas species are ubiquitous water borne organisms and cause gastrointestinal infection in humans (Horneman et al., 2007). Aeromonas species comprises of mesophillic motile and psychrophilic nonmotile gram negative bacterium. Three distinctive gastroenteritis are caused by Aeromonas spp. (a) acute watery diarrhoea, (b) dysentery and (c) sub acute or chronic diarrhoea (Janda et al., 1998). Acute diarrhoeal diseases constitute an important cause of morbidity and mortality throughout the world, particularly among the infants and children in developing countries (Rao et al., 1965). According to the World Health Organization (WHO), diarrhoeal diseases are among the ten major causes of death among young children in eleven countries of Africa, Asia and South America. The 
species principally associated with gastroenteritis are A. caviea, A. hydrophila and $A$. veronii bio varsobria (Joseph et al., 1996). The outbreak of cholera has been reported in Odisha from time to time. The major etiological agents are different strains of E. coli, Shigella spp. and V. cholerae, which has been reported by different researchers (Chhotray et al., 2002, Palet al., 2000, Albert et al., 1995). So far, no study has been conducted on Aeromonas related diarrhoea in Odisha. So, the present study has been envisaged to know the prevalence of Aeromonas spp. related to gastroenteritis by isolation, characterization and genetic analysis isolated from indoor diarrhoea patients and water samples from the coastal districts of Odisha.

\section{Materials and Methods}

\section{Bacterial culture analysis}

The rectal swabs were collected from hospitalized diarrhoea patients before the administration of antibiotics in Cary Blair's transport medium between September, 2006-August, 2007. The samples were immediately incubated in double strength APW and GN broth for 24 hrs. Then the samples were streaked into the MacConkey, TCBS agar and HEA plates (HiMedia, Mumbai). The samples from water and diarrhoea patients also were streaked into Aeromonas isolation agar and Rimler Shott's medium. The hemolytic activity of Aeromonas species were done in Blood agar (HiMedia, Mumbai) plates by taking 5\% sheep blood. Blood agar plates were incubated in aerobic and anaerobic conditions at $37^{\circ} \mathrm{C}$ for $24 \mathrm{hrs}$. The degree of hemolysis was measured for species detection. Significant colonies were picked up for gram staining and finally biochemical test was done for confirmation. Identification of strains was done based on colony morphology, motility test and biochemical tests like urease, TSI, manitol motility, indole, citrate utilization, oxidase, methyl red, voges-proskauer, ONPG, KIA chain, oxidation-fermentation, starch hydrolysis, sugar fermentation, deaminase, decarboxylase, gelatinase, etc ( HiMedia, Mumbai) (Pal et al., 2000).

\section{Antimicrobial Susceptibility}

Antibiotic susceptibility analysis was performed by modified Kirby Bauer Disk diffusion technique (Bauer et al., 1966) with commercially available antibiotic disc (HiMedia-Mumbai). Characterization of stains as susceptible, intermediately resistant or resistant were done as based on the size of the inhibition zone according to the manufacturer's instruction which matched the interpretive criteria recommended by WHO. Antibiotics used in this study were

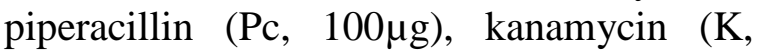
$10 \mu \mathrm{g})$, gentamicin $(\mathrm{G}, 10 \mu \mathrm{g})$, bacitracin $(\mathrm{B}$, $10 \mu \mathrm{g})$, rifampicin $(\mathrm{R}, 30 \mu \mathrm{g})$, trimethoprim (Tr, 30 $\mu \mathrm{g})$, cefotaxime (CTX, $30 \mu \mathrm{g}$ ), erythromycin $(\mathrm{E}, 15 \mu \mathrm{g})$, sulfadiazine $(\mathrm{SD}$, $25 \mu \mathrm{g}$ ), roxithromycin (RXT, $15 \mu \mathrm{g}$ ), lomafloxacin (LOM, $10 \mu \mathrm{g}$ ), azithromycin (AZM, $15 \mu \mathrm{g})$, cefuroxime $(\mathrm{Cu}, 30 \mu \mathrm{g})$, doxycycline $(\mathrm{dx}, 30 \mu \mathrm{g})$, tetracycline $(\mathrm{T}$,

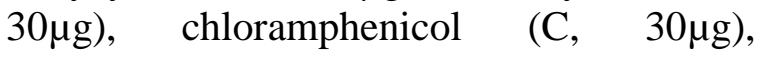

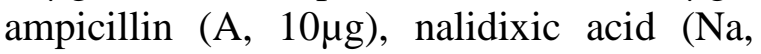
$30 \mu \mathrm{g})$, furazolidone $(\mathrm{Fr}, 50 \mu \mathrm{g})$, norfloxacin $(\mathrm{Nx}, 10 \mu \mathrm{g})$, ciprofloxacin (Cf, $5 \mu \mathrm{g})$, cotrimoxazole (Co, 25 $\mu$ g), amikacin (Ak,

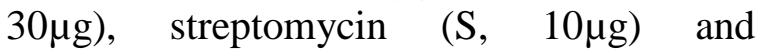
amoxicillin (Am,10 $\mu \mathrm{g})$.

\section{PCR assay}

The PCR assay was done for the detection of hly A gene of Aeromanas spp. isolated from water and stool samples. The DNA was isolated from culture grown in Luria Bertani (LB) broth for overnight by boiling in a 
water bath for $10 \mathrm{~min}$ and instant cooling on ice. The forward primer sequence (F: 5'GAGACTGCAGATGCCAAAAGTCAATC GTTGCGCAATC-3') and the reverse primer sequence (R: 3' GAGAGAATTCTTAGTGCAAATCAAAT TGAACCCCTTTCACCAA-5') were used in this assay (3B Black Bio Biotech India Ltd). The reaction mixture was prepared with preparation of master mix by adding adequate water, buffer, dNTP, hlyA gene, primer 1 and 2 and Taq DNA polymerase. The thermal cycle condition for this assay was $94^{\circ} \mathrm{c}$ for $4 \mathrm{~min}$, initial denaturation; $94^{\circ} \mathrm{C}$ for $1 \mathrm{~min}$, denaturation; $65^{\circ} \mathrm{C}$ for 1.5 min, annealing; $72^{\circ} \mathrm{C}$ for $2.5 \mathrm{~min}$, extension; for 30 cycles, $72^{\circ} \mathrm{C}$ for $7 \mathrm{~min}$, final extension. The PCR product will be electrophorated and the specific DNA brands was visualized under UV illumination (Sinha et al., 2004).

\section{RAPD- PCR assay}

RAPD-PCR assay of Aeromonas species were done by taking random primer 1281 (5' AAGGCGCAAC-3') (3B Black Bio Biotech India Ltd) in a 25 micro liter reaction mixture to calculate the genetic similarity between the strains. The template DNA was prepared similarly as PCR assay. Amplification was done with appropriate vol. of $2.5 \mu \mathrm{l}$ of $10 \mathrm{X}$ amplification buffer, $2.5 \mu 1$ each of DNTPs, $1.0 \mu \mathrm{l}$ of each primer, $0.3 \mu \mathrm{l}$ of $\mathrm{Taq}$ DNA polymerase and $2 \mu \mathrm{l}$ of template DNA. The reaction volume was adjusted to $25 \mu \mathrm{l}$ using sterile triple distilled water. The cycling program was initial denaturation at $95^{\circ} \mathrm{C}$ for $30 \mathrm{sec}$ and final extension at $72^{\circ} \mathrm{C}$ for $10 \mathrm{~min}$; cycling conditions were $94^{\circ} \mathrm{C}$ for $1 \mathrm{~min}, 36^{\circ} \mathrm{C}$ for 1 min and $72{ }^{\circ} \mathrm{C}$ for $2 \mathrm{~min}$, continued for 45 cycles. After completion, 8 micro liter aliquots of products were done for electrophoresis in $1.2 \%$ agarose gel containing 1 microgram ethidium bromide and visualized under UV light (Sinha et al., 2004). Genetic similarity of Aeromonas species was calculated using the formula $\mathrm{N}_{\mathrm{AB}}=2 \mathrm{~S}_{\mathrm{AB}} / \mathrm{S}_{\mathrm{A}}+\mathrm{S}_{\mathrm{B}}$; in which $\mathrm{N}_{\mathrm{AB}}=$ Genetic similarity between two strains $A \& B$, $\mathrm{S}_{\mathrm{AB}}=$ No. of amplified bands shared common between $A \& B$ and $S_{A} \& S_{B}=$ Total no. of amplified bands present in strains $\mathrm{A}$ and $\mathrm{B}$ respectively.

\section{Results and Discussion}

\section{Bacteriological analysis}

A total of two hundred and eighty rectal swabs and 100 water samples collected during the study period were bacteriological analyzed using standard techniques. The bacteriological analysis of stool samples revealed $44.3 \%$ were culture positive of which $20.2 \%$ were Aeromonas spp., followed by other pathogens as $31.5 \%$ of $V$. cholerae, E. coli $-43.5 \%$, Shigella spp. $4.8 \%$ (Table-1). The distribution of the bacterial pathogens from different water samples were as, Aeromonas spp., $V$. cholerae non $\mathrm{O} 1$ and non $\mathrm{O} 139$ and $E$. coli as shown in table 2. Out of 100 samples $40 \%$ were isolated from ponds, $37 \%$ from well, $12 \%$ from lake and $11 \%$ from canal water respectively (Table-2). Out of 100 water samples, 30 (62.5\%) Aeromonas spp. was isolated, out of which 17 isolates were A. hydrophila, 8 were A. caviae and 5 were A. sobria respectively.

The different species of Aeromonas isolated (A. hydrophila, A. caviae and A. sobria) (Table-3) were different from each other in lysine decarboxylase, esculin hydrolysis, and nitrate test, production of hydrogensulphide and in fermentation of different sugars. A. hydrophila used L-histidine, Larabinose, L-arginine and salicin as sole carbon source. They hydrolyzed esculine, grew in $\mathrm{KCN}$ medium, fermented salicin, and produced gas from glucose and $\mathrm{H}_{2} \mathrm{~S}$ 
from cysteine. A. caviae strains used Lhistidine, L-arabinose and salicin as sole carbon source. They hydrolyzed esculine, grew in $\mathrm{KCN}$ medium, fermented salicin, did not produce gas and acetoin from glucose or $\mathrm{H}_{2} \mathrm{~S}$ from cysteine. A. sobria did not use L-histidine, L-arabinose, L-arginine and salicin as sole carbon source. They did not hydrolyze esculine, do not ferment salicin. They produced gas from glucose and produced $\mathrm{H}_{2} \mathrm{~S}$ from cysteine.

\section{Antibiogram profile}

The different Aeromonas species (A. hydrophila, A. caviae and A. sobria) were multidrug resistant. They were sensitive to gentamicin, trimethoprim, azithromycin, tetracycline, doxycycline, chloramphenicol, nalidixic acid, norfloxacin, co-trimoxazole, amikacin and streptomycin; but were resistant to a number of antibiotics such as piperacillin, kanamycin, bacitracin, rifampicin, erythromycin, sulfadiazine, roxithromycin, lomefloxacin, ciprofloxacin, ampicillin, furazolidone, cefuroxime, and amoxicillin (Table-4).

\section{PCR assay result}

Twenty nine $(52.7 \%)$ strains of Aeromonas spp. showed $\beta$-hemolysis on blood agar plates. The degree of hemolysis between different strains of Aeromonas spp. varied from 1.17 to 1.57 ; in $A$. caviae from 1.18 to 1.46 in $A$. sobria from 1.23 to 1.35 respectively. Among the Aeromonas spp.; 13 strains of $A$. hydrophila, 8 strains of $A$. caviae and 8 strains of $A$. sobria showed $\beta$ hemolysis (table-3) and the results were corelated with the presence of hyl A (702bp) gene as detected in PCR assay (Fig- 1).

\section{RAPD-PCR Assay}

RAPD-PCR Assay of Aeromonas spp. (Fig: 2) produced 4 to 8 amplified fragments of molecular weight varied from 181 to 2111 bp respectively. The strains of $A$. hydrophila produced 4 to 5 amplified bands of molecular weight varied from 181 to $2472 \mathrm{bp}$ in A. caviae strains produced 5 amplified bands of molecular weight 181 to 2512 bp and in A. sobria strains produced 8 amplified fragments of molecular weight varied from 281 to 4572 bp respectively. The amplified fragments as 2472, 1493, $833,820,679,658,598,544$ and $181 \mathrm{bp}$ were common within the different strains of Aeromonas spp. The genetically similarity value of the strains of Aeromonas spp. varied from 0.308 to 1.0 ; similarity value between the strains of $A$. hydrophila and $A$. caviae varied from 0.4 to 1.00 between strains of $A$. hydrophila and A. sobriavaried from 0.308 to 0.462 respectively. The genetic similarity between the strains of $A$. caviae and $A$. sobria were varied from 0.308 to 0.462 . Thus it is concluded that the strains of three Aeromonas spp. were quite similar as observed in RAPD-PCR assay, through the above strains were isolated from different sources. The phenotypic and genotypic characters, different toxic gene of Aeromonas spp. isolated from environmental and clinical sources were quite similar which caused diarrhoea, dysentery and gastroenteritis in human beings.

The role of Aeromonas spp. has been recognized for some time (Janda et al., 1998), but only during the past three decades their role in a variety of human illness has been documented. The role of Aeromonas spp. in bacterial gasteroanteritis is not yet clearly understood owing to a paucity of long term studies (Janda et al., 1998) and the inability to differentiate between pathogenic and nonpathogenic strains. The present study was envisaged to determine the existence of different Aeromonas spp. isolated from water and diarrhoea patients. 
Table.1 Incidence of Aeromonas spp. isolated from stool samples

\begin{tabular}{|l|l|l|l|l|l|l|l|}
\hline Sl.No. & Hospitals & $\begin{array}{l}\text { Total } \\
\text { samples }\end{array}$ & $\begin{array}{l}\text { Culture } \\
+ \text { ve }\end{array}$ & Culture -ve & $\begin{array}{l}\text { Aeromonas } \\
\text { spp. }\end{array}$ & V.cholerae & $\begin{array}{l}\text { E. coli } \\
\text { spp. }\end{array}$ \\
\hline 1. & BBSR \& Cuttack & $58(20.7)$ & $21(16.9)$ & 37 & 6 & 12 \\
\hline 2. & Puri & $222(79.3)$ & $103(83.1)$ & 119 & 19 & 1 & 37 \\
\hline & Total & 280 & $124(44.3)$ & $156(55.7)$ & $25(20.2)$ & $39(31.5)$ & 5 \\
\hline
\end{tabular}

Table.2 Isolation of Aeromonas spp. from different water sources

\begin{tabular}{|l|l|l|l|l|l|l|l|}
\hline Sl. No. & $\begin{array}{l}\text { Water } \\
\text { Sources }\end{array}$ & $\begin{array}{l}\text { Total } \\
\text { Sample } \\
\text { S }\end{array}$ & $\begin{array}{l}\text { Culture } \\
+ \text { ve }\end{array}$ & $\begin{array}{l}\text { Culture }- \\
\text { ve }\end{array}$ & $\begin{array}{l}\text { Aeromonas } \\
\text { spp. }\end{array}$ & V.cholera & E. coli \\
\hline 1. & Pond & 40 & 20 & 20 & 15 & 1 & 3 \\
\hline 2. & Well & 37 & 18 & 19 & 10 & 3 & 5 \\
\hline 3. & Lake & 12 & 5 & 7 & 3 & 0 & 2 \\
\hline 4. & Canal & 11 & 5 & 6 & 2 & 1 & 1 \\
\hline & total & 100 & 48 & 52 & $30(62.5)$ & $5(10.4)$ & $11(22.9)$ \\
\hline
\end{tabular}

Table.3 Total percentage of hemolysis and hlyA gene from stool and water samples.

\begin{tabular}{|l|l|l|l|l|l|l|}
\hline $\begin{array}{l}\text { Types of } \\
\text { Aeromonas }\end{array}$ & $\begin{array}{l}\text { Stool } \\
\text { Samples }\end{array}$ & $\begin{array}{l}\text { Water } \\
\text { Samples }\end{array}$ & \multicolumn{2}{|l|}{ Hemolysis } & \multicolumn{2}{l|}{ hlyA gene } \\
\hline & & & Stool & Water & Stool & Water \\
\hline A. hydrophyla & $11(44 \%)$ & $17(56.7)$ & 4 & 9 & 4 & 9 \\
\hline A. caviae & $7(28 \%)$ & $8(26.7)$ & 2 & 6 & 2 & 6 \\
\hline A. sobria & $7(28 \%)$ & $5(16.7)$ & 4 & 4 & 4 & 4 \\
\hline Total & 25 & 30 & $10(40 \%)$ & $19(63.3 \%)$ & $10(40 \%)$ & $19(63.3 \%)$ \\
\hline
\end{tabular}


Table.4 Resistance profiles (\%) of Aeromonasspp.isolates from clinical and environmental samples.

\begin{tabular}{|c|c|c|c|c|c|c|c|c|c|c|c|c|c|c|c|c|c|c|c|c|c|c|c|c|c|c|}
\hline & & $\mathrm{A}$ & B & $\mathrm{C}$ & $\mathrm{D}$ & $\mathrm{E}$ & $\mathrm{F}$ & $\mathrm{G}$ & $\mathrm{H}$ & I & $\mathrm{J}$ & $\mathrm{K}$ & $\mathrm{L}$ & $\mathrm{M}$ & $\mathrm{N}$ & $\mathrm{O}$ & $\mathrm{P}$ & Q & $\mathrm{R}$ & $\mathrm{S}$ & $\mathrm{T}$ & $\mathrm{U}$ & $\mathrm{V}$ & $\mathrm{W}$ & $\mathrm{X}$ & $\mathrm{Y}$ \\
\hline \multirow[t]{2}{*}{ A.hydrophyla } & $\mathrm{S}$ & 100 & 100 & 20 & 80 & 80 & 60 & 60 & 80 & 80 & 80 & 80 & 80 & 80 & 80 & 40 & 100 & 100 & 100 & 60 & 80 & 100 & 80 & 80 & 40 & 100 \\
\hline & $\mathrm{W}$ & 94.1 & 82.4 & 35.3 & 94.1 & 56.6 & 11.8 & 64.7 & 88.2 & 94.1 & 88.2 & 56.6 & 23.5 & 88.2 & 58.8 & 27.7 & 94.1 & 58.8 & 94.1 & 94.1 & 64.7 & 70.6 & 64.7 & 76.5 & 29.4 & 100 \\
\hline \multirow[t]{2}{*}{ A.caviae } & $S$ & 100 & 100 & 0 & 66.7 & 66.7 & 33.3 & 66.7 & 66.7 & 66.7 & 66.7 & 66.7 & 66.7 & 66.7 & 33.3 & 33.3 & 100 & 100 & 100 & 66.7 & 66.7 & 66.7 & 0 & 66.7 & 33.3 & 66.7 \\
\hline & $\mathrm{W}$ & 83.3 & 100 & 0 & 83.3 & 66.7 & 0 & 33.3 & 66.7 & 83.3 & 66.7 & 0 & 0 & 66.7 & 50 & 0 & 100 & 0 & 100 & 0 & 50 & 83.3 & 66.7 & 83.3 & 50 & 88.3 \\
\hline \multirow[t]{2}{*}{ A.sobria } & $\mathrm{S}$ & 100 & 66.7 & 0 & 66.7 & 66.7 & 0 & 0 & 66.7 & 66.7 & 66.7 & 66.7 & 0 & 66.7 & 33.3 & 33.3 & 100 & 33.3 & 100 & 0 & 66.7 & 0 & 0 & 0 & 33.3 & 100 \\
\hline & $\mathrm{W}$ & 75 & 100 & 0 & 75 & 50 & 0 & 25 & 75 & 100 & 75 & 75 & 50 & 75 & 25 & 0 & 100 & 50 & 100 & 0 & 75 & 50 & 75 & 50 & 0 & 75 \\
\hline
\end{tabular}

S: Rectal swab, W: Water samples;

A-piperacillin (Pc); B- kanamycin (K); C-gentamicin (G); D- bacitracin (B); E-rifampicin (R); F-trimethoprim (Tr); G-cefotaxime (CTX); H- erythromycin (E); I-sulfadiazine (SD); J-roxithromycin (RXT); K-lomefloxacin (LOM); L- azithromycin (AZM); Mciprofloxacin (Cf); N- tetracycline (T), O- chloramphenicol (C); P- ampicillin (A); Q- nalidixic acid (Na); R- furazolidone (Fr), Snorfloxacin $(\mathrm{Nx})$, T- cefuroxime $(\mathrm{Cu})$; U- co-trimoxazole $(\mathrm{Co})$; V- amikacin $(\mathrm{Ak})$; W-doxycycline $(\mathrm{Dx})$; X-streptomycin (S) and Yamoxicillin (Am).

Fig.1 Detection of hly A(720bp) gene of Aeromonas isolates. Lane 1, 100bp ladder; Lane 2-3, A. hydrophila strains ; Lane 4-5, A. caviae strains; Lane 6, A. sobria strains

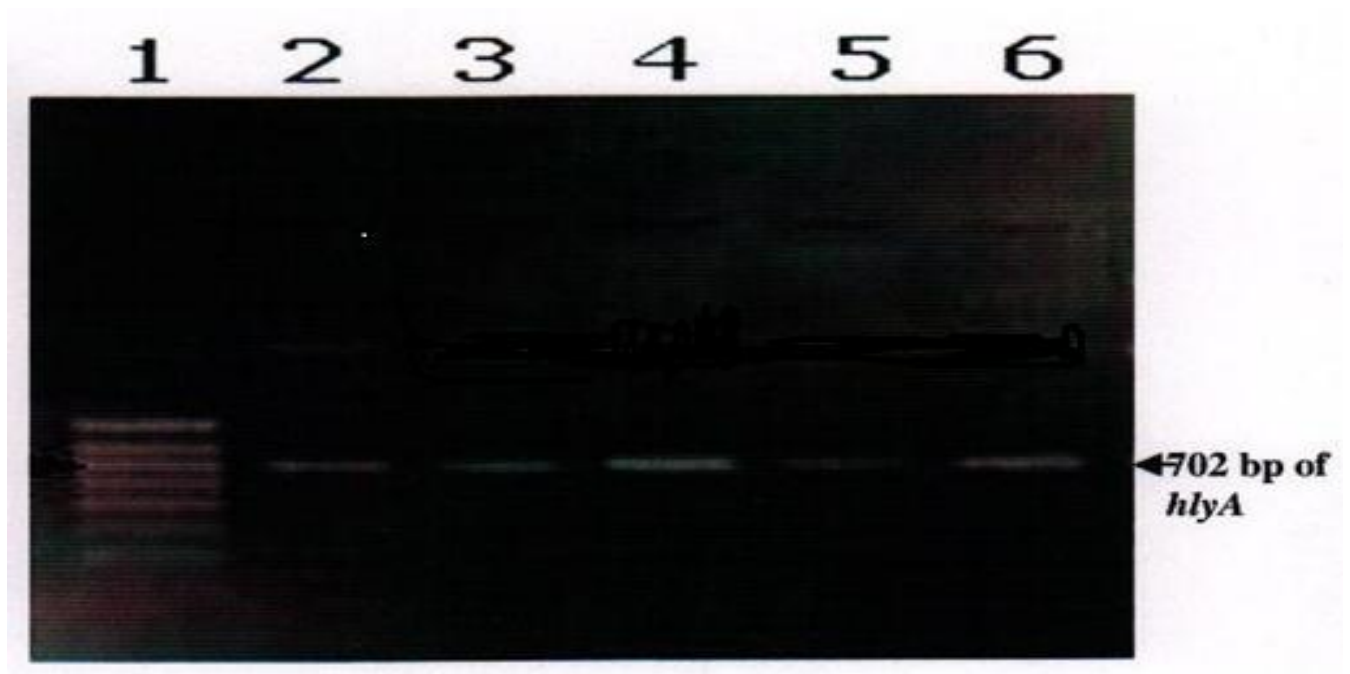


Fig.2 RAPD PCR of Aeromonas spp. using primer 1281. Lane 1, 1KB DNA ladder; Lane 2-3, A. hydrophila strains; Lane 6-7, A. caviae strains; Lane 8-9, A. sobria strains.




The present study demonstrated that Aeromonas spp. were associated with acute diarrhoea at least in $20.2 \%$ of patients. It is difficult to predict the importance of Aeromonas in 280 cases, as these patients were co-infected by other pathogens.

Out of 100 samples collected from water and 280 samples from diarrhoea patients, we found $56.7 \%$ A. hydrophila, $26.7 \% A$. caviaeand $16.7 \%$ A. sobria strains from environmental and $44 \%$ A. hydrophila, $28 \%$ A. caviae and $28 \%$ A. sobria strains from clinical samples respectively. The low prevalence of $A$. hydrophila suggested that it might have some etiological significance in the diarrhoea patients.

Examination of the water from the different sources suggested that the organism might have originated from water and that the gastrointestinal tract is a common habitat of human strains, as reported by other workers (Aldová et al., 1966). Wilcox et al., (1992) reported that the prevalence of $4.4 \%$ Aeromonas spp. in the faeces of pediatric inpatient, Salmonella- $2.2 \%$ and Rotavirus$2.5 \%$. In our study we reported $20.2 \%$ of Aeromonas spp., followed by other pathogens as $13.5 \%$ of $V$. cholerae, E. coli $43.5 \%$, Shigella spp. $-4.8 \%$.

We found $A$. hydrophila as the dominant species causing diarrhoea in Odisha. A study from south India has revealed that $A$. hydrophila is the prominent species which co-relates our findings (Komathi et al., 1998). In Bangladesh, A. trota was isolated from large number of diarrhoea patients (Albert et al., 2000); however this species was not found in hospitalized diarrhoea cases in Odisha. Ørmen, et al., (2001) revealed the existence of five different phenol species of Aeromonas in four springs of Norway as A. hydrophila (42\%), A. schobertii (22\%), A. caviae (19\%), A. sobria
(16\%) and A. veronii bio var sobria (1\%). Sinha et al. (2004) from Kolkata reported that the Aeromonas strains revealed different virulence gene combinations by PCR assay.

The dominant combination of enterotoxin genes were alt (71.9\%), act (20.1\%) and hyl A $(28 \%)$. The presence of the above three exotoxins in various combinations in different Aeromonas strains could increase or decrease the expansion of the specific exotoxin gene and thus dictate the severity of diarrhoea (Sha et al., 2002). In our present study we found $52.7 \%$ of the Aeromonas strains showed hyl A gene; of which $44.8 \%$ of $A$. hydrophila, $27.6 \%$ of $A$. caviae and $27.6 \%$ of A. sobria strains respectively. The genetic similarity value of the strains of Aeromonas species varied from 0.308 to 1.0. The genetic similarity between the strains of $A$. caviae and $A$. sobria varied from 0.308 to 0.462 . The RAPD PCR assay showed that Aeromonas strains were genetically heterogeneous and no particular clone was predominant in Odisha. Species of Aeromonas are capable of expressing a number of extracellular toxins and enzymes (Howard et al., 1996). Early characterization of the toxins, however, resulted in confusion regarding their number and activities. Clinical and environmental isolates secretes many extra cellular products such as hemolysin, enterotoxin, aerolysin, haemagglutinin. Among these toxins, aerolysin is released as a protoxin which is activated by protease released by the bacteria (Hilton et al., 1991, Rodriguez et al., 1992).Species of Aeromonas also produce a range of cellsurface and secreted proteases which probably enhance virulence (Howard et al., 1996). Expression of virulence factors including haemolysins and proteases, by aeromonads has been shown to be influenced by environmental temperature (Eley et al., 1993, Mateos et al., 1993). 
Despite the association of virulence factors with drinking-water aeromonads, there is increasing evidence that strains isolated from the environment generally belong to different groups of strains associated with gastroenteritis.

In conclusion, the present study clearly indicates that different Aeromonas spp. were one of the etiological agents of diarrhoea among hospitalized diarrhoea patients from Odishawhich is the first report from this state. The different Aeromonas species were harboring toxic gene like hly A and showed multiple drug resistance as observed from this study. So, this type of study should be extended in other parts of the state enrolling more number of water samples and diarrhoea patients together.

\section{Acknowledgement}

We extend our sincere thanks to the chief medical officer and the staffs of Capital Hospital, Bhubaneswar; SCB Medical College and hospital, Cuttack and ID Hospital of Puri respectively for their kind cooperation and help during sample collection. We are thankful to the Director, RMRC, Bhubaneswar for his support for this work.

\section{References}

Horneman, A.J., Ali, A., Abbott, S.L. 2007 Edited by Murray, P.R., Aeromonas. Washington, DC: American Society for Microbiology. In Manual of Clin Microbiol; 716-22.

Janda, J.M., Abbott, S.L. 1998. Evolving Concepts Regarding the Genus Aeromonas: An Expanding Panorama of Species. Disease Presentations, and Unanswered Questions, Clin Infect Dis ; 27: 332-44.

Rao, M.K., Murti, B.R. 1965. A study of bacterial aetiology of diarrhoea and dysentery in infants and children. $J$ Ass Phycns India; 13: 557.

Joseph, S.W. $1996 . \quad$ Aeromonas gastrointestinal disease: A case study in causation? In: The Genus: Aeromonas, 1st ed. Austin, B., Altwegg, M., Gosling, P.J., Joseph, S.W., editors. John Wiley \& Sons, Ltd, Chichester; 311-35.

Chhotray, G.P., Pal, B.B., et al. 2002. Incidence and molecular analysis of Vibrio cholerae associated with cholera outbreak subsequent to the super cyclone in Orissa. India, Epidemiol Infect; 128: 131-8.

Pal, B.B., Khuntia, H.K., Anuradha, A., Chhotray, G.P. 2000. Emergence of Vibrio cholerae 0139 sero group during 1995 in Orissa, India: A retrospective study. Indian $J$ Med Microbiol; 18: 195-6

Albert, M.J., Faruque, S.M., et al. 1995. Controlled study of Escherichia coli diarrheal infections in Bangladeshi children. J ClinMicrobiol; 33: 973-7.

Bauer, A.W., Kirby, W.M.M., Sherries, J.C., Turek, M. 1966. Antibiotic susceptibility testing by a standardized single disc method. American J Clin Pathogens; 45:493-6.

Sinha, S., Shimada, T., et al. 2004. Prevalence, serotype distribution, antibiotic susceptibility and genetic profiles of mesophilic Aeromonas species isolated from hospitalized diarrhoeal cases in Kolkata, India. J Med Microbiol; 53(Pt 6):527-34.

Aldová, E., Rakovský, J., Chovancová, A. 1966. The microbiological diagnostics of strains of Aeromonas shigelloides isolated in Cuba. J Hyg Epidemiol Microbiol Immunol; 10(4):470-82.

Wilcox, M.H., Cook, A.M., Eley, A., Spencer, R.C. 1992. Aeromonas spp as a potential cause of diarrhoea in 
children. J Clin Pathol; 45(11): 95963.

Komathi, A.G., Ananthan, S., Alavandi, S.V. $1998 . \quad$ Incidence \& enteropathogenicity of Aeromonas spp in children suffering from acute diarrhoea in Chennai. Indian J Med Res; 107:252-6.

Albert, M.J., Ansaruzzaman, M., et al. 2000. Prevalence of enterotoxin genes in Aeromonas spp. isolated from children with diarrhea, healthy controls, and the environment. $J \quad$ Clin Microbiol; 38(10):3785-90.

Ørmen, Ø., Østensvik, Ø. 2001. The occurrence of aerolysinpositive Aeromonas spp. and their cytotoxicity in Norwegian water sources. J Appl Microbiol; 90(5): 797802.

Sha, J., Kozlova, E.V., Chopra, A.K. 2002. Role of various enterotoxins in Aeromonas hydrophila-induced gastroenteritis: generation of enterotoxin gene-deficient mutants and evaluation of their enterotoxic activity. Infection and Immunity; 70: 1924-35.

Howard, S.P., MacIntyre, S., Buckley, J.T. 1996. Toxins. In: The genus
Aeromonas. Ed. Austin, B., et al. London, Wiley; 267-86.

Hilton, S., Buckley, J.T. 1991. Studies on the reaction mechanism of a microbial lipase/acyltransferase using chemical modification and site-directed mutagenesis. $J$ Biol Chem; 266(2):997-1000.

Rodriguez, L.A., Ellis, A.E., Nieto, T.P. 1992. Purification and characterization of extracellular metalloprotease, serine protease and of Aeromonas hydrophila strain B32: all are lethal for fish. Micro Pathog; 13 (1):17-24.

Eley, A., Geary, I., Wilcox, M.H. 1993. Growth of Aeromonas spp. at $4{ }^{\circ} \mathrm{C}$ and related toxin production. Letters in Applied Microbiology; 16: 36-9.

Mateos, D., Anguita, J., Naharro, G., Paniagua, C. 1993. Influence of growth temperature on the production of extracellular virulence factors and pathogenicity of environmental and human strains of Aeromonas hydrophila. J Appl Bacteriology; 74:111-8.

\section{How to cite this article:}

Bibhuti Bhusan Pal, Sanjay Kumar Pattnaik, Anima Mohanty, Surya Kanta Samal, Hemant Kumar Khuntia and Sukanta Kumar Nayak. 2016. Incidence of Aeromonas species isolated from Diarrhoea patients and water samples from coastal districts of Odisha, India. Int.J.Curr.Microbiol.App.Sci. 5(7): 990-999. doi: http://dx.doi.org/10.20546/ijcmas.2016.507.111 